\title{
HOW CHERRY COKE SAVED MY LIFE
}

\section{A luckybreak.}

\section{BY DAWN BONANNO}

CC A meetings didn't work A for me," I told the little alien. I didn't know what to do with him. He kind of looked like a poodle, so it seemed like I was sitting on my front stoop talking to a dog I didn't own. As if the hawk-eye neighbours didn't think I was strange enough, living in this big house all by my lonesome. Well, what used to be my house. At least the pond was still intact, pretty as it reflected the afternoon sun in purple ripples.

"A ... A?" His puppy-dog eyes crossed.

"A place where drunks go to cure themselves. Works for millions of Americans. Just not ol' Harold. It was the crowds, you see. Even the smaller meetings were too crowded for me. Some guy offered to mentor me solo, but then I'd lose the anonymous part of the deal. The guy would know me. People would hear about the screwball who was so far gone even AA couldn't help him."

Poodle guy nodded, his ear curls bouncing. "My translator is functioning properly now. Allow me to introduce - "

I grabbed his snout. Not hard, just enough to make him shut up. "Anonymity, dude. Work with me here." Not giving him a chance to realize I'd already introduced myself, I went on. "So that was around when Jenna left me, and I was really in hot water. I don't cook. Sure as hell can't clean. She took care of me and the kids, but after I got fired, she was done. I almost died without her."

"Is that when the Cherry Coke saved your life?"

"Not yet, but it is when I started on the Cherry Coke. Had to transfer my dependence onto something that wouldn't get me fired again or permanently divorced or smash my wheels. Figured the Coke was a good idea as I'd already done in my liver with all that drinking. As long as I drink extra water and run a bit, my kidneys'll hold up. The running did me some serious good. It lost me thirty pounds."

I felt like scratching behind his ears, but he'd probably take offence to that, being new to Earth and all, and not knowing our relationship with the resident four-leggers. Have to give him credit for just looking at me all strange.

"Thirty pounds." Poodle guy cocked his head to the side then nodded. "Removing $15 \%$ of your body mass would seriously relieve the stress on your internal organs. Is that how Cherry Coke saved your life?"

"Nah. The running was good, but it wasn't life-changing or nothing." What was he, a doctor or something? If that was the case, he wouldn't be much help with my house. "See, I still want Jenna back. I called her today, told her about all I done, invited her over. Damn but she said yes! I started shaking all over, and that's when I realized I needed a Coke. Crappy timing though, I was all out."

The poodle guy nodded, his ears flopping, as if making some big discovery from my troubles. "Out of inventory?"

I snorted. "I put a dent in the A\&P's inventory, filled up my trunk. Didn't even $\rightarrow$ NATURE.COM

Follow Futures: y @NatureFutures

f go.nature.com/mtoodm for gas, which my wheels needed to get me back here. So I was late for Jenna. Saw her driving back and caught some nasty words, but she never did slow down. Don't think she'll be back."

"Is that how Cherry Coke saved your life?"

"Nah." I grinned now and this time I pet him on the head. Probably confused him more than it ticked him off. I took a long swig of my warm Cherry Coke, finishing off the can. "See, the Cherry Coke? It got me out of the house and stuck on those back roads when you lost control of your damned saucer -" "Spacepod."

"I don't care what you call it, it trashed my house. Look at it! How the hell am I supposed to live in a pile of smashed timber and space metal? That's what I was thinking as I walked up, soda case in hand. Yep. If it weren't for the Cherry Coke, I'd have been home, pacing my living room when your saucer crashed down onto it. So you see, my furry friend, that's how Cherry Coke saved my life."

Poodle guy was silent as he stared at the wreckage of my empty home. Not that I cared about the house itself. Like I said, can't clean. If Jenna had actually gone in, she'd have left me again on account of being a slob. At least I had a dog now. Sort of.

"Welcome to Earth, friend," I said.

"Oh no," he said and stared wide-eyed at the wreckage.

"What, dude?"

"Wrong planet." He whimpered now.

"That sucks. Will your friends come rescue you?"

"I was supposed to rescue them."

The debris that had been my house shifted, the timber and metal collapsing in on itself. Homeless is homeless, it didn't matter what that mess did now.

"Shit happens, friend," I said, deciding to keep him, and opened him up a warm can of Cherry Coke. "Best you can do is live in the moment. You never know what might come of it." -

Dawn Bonanno suffers from an obsession with pens, paper and fixing things, so it only makes sense that she writes stories. Rumours of her Cherry Coke addiction have been documented at www.dmbonanno.com. 